\title{
Transitional dynamics of dividend and capital gains tax cuts is
}

\author{
François Gourio $^{\mathrm{a}, \mathrm{b}}$, Jianjun Miao ${ }^{\mathrm{a}, \mathrm{c}, *}$ \\ a Department of Economics, Boston University, 270 Bay State Road, Boston, MA 02215, United States \\ b NBER, United States \\ ${ }^{\mathrm{c}}$ CEMA, Central University of Finance and Economics, China
}

\section{A R T I C L E I N F O}

\section{Article history:}

Received 26 November 2008

Revised 4 June 2010

Available online 30 June 2010

\section{JEL classification:}

D92

E22

E62

G31

G32

H32

Keywords:

Capital gains tax

Dividend tax policies

Investment and financial policies

Finance regimes

Collateral constraint

Intertemporal tax arbitrage

\begin{abstract}
A B S T R A C T
We develop a dynamic general equilibrium model to study the impact of the 2003 dividend and capital gains tax cuts. In the model, firms are heterogeneous in productivity and make investment and financing decisions subject to capital adjustment costs, equity issuance costs, and collateral constraints. We show that when the dividend and capital gains tax cuts are unexpected and permanent, dividend payments, equity issuance, and aggregate investment rise immediately. By contrast, when these tax cuts are unexpected and temporary, aggregate investment falls in the short run. This fall allows firms to distribute large dividends initially in response to the temporary dividend tax cut. We also find that the effects of a temporary dividend tax cut are very different from those of a temporary capital gains tax cut.
\end{abstract}

(c) 2010 Elsevier Inc. All rights reserved.

\section{Introduction}

A large literature in macroeconomics and public finance studies the effects of tax reforms on the economy. ${ }^{1}$ A central result is that the effects can be quite different depending on whether the tax changes are expected or unexpected, and are temporary or permanent. This result appears relevant because recent tax reforms often specify phase-ins or sunsets. In this paper, we focus on the dividend and capital gains tax reform of 2003. The Jobs and Growth Tax Relief Reconciliation Act (JGTRRA) reduced the tax rates on dividends and capital gains and eliminated the wedge between these two tax rates through 2008. These tax cuts were later extended through 2010. There is a significant debate on whether these tax cuts will expire, or will be extended again.

\footnotetext{
We thank Alan Auerbach, Christophe Chamley, Simon Gilchrist, Bob King, Anton Korinek, Larry Kotlikoff, and Jim Poterba (AEA discussant), and seminar participants at the Boston University macro lunch, Hong Kong University of Science and Technology, and the 2008 American Economic Association Meeting at New Orleans for helpful comments. We are especially grateful to Ellen McGrattan (editor) and an anonymous referee for useful suggestions and comments. This paper is an overhaul of our earlier paper "Dynamic Effects of Permanent and Temporary Dividend Tax Policies on Corporate Investment and Financial Policies". Part of this research was conducted when Miao was visiting Hong Kong University of Science and Technology. The hospitality of this institution is gratefully acknowledged.

* Corresponding author at: Department of Economics, Boston University, 270 Bay State Road, Boston, MA 02215, USA.

E-mail addresses: fgourio@bu.edu (F. Gourio), miaoj@bu.edu (J. Miao).

1 See e.g. Abel (1982), Auerbach (1989), and Auerbach and Kotlikoff (1987). Also see Ljungqvist and Sargent (2004) for a textbook treatment.
} 
The objective of this paper is to study the dynamic effects of temporary and permanent changes in dividend and capital gains taxes on the economy in a dynamic general equilibrium model with firm heterogeneity in productivity. Previous tax analyses typically adopt the neoclassical growth model framework with a representative firm. In a nonstochastic steady state, the representative firm is able to finance its investment using retained earnings, and the dividend taxation is irrelevant. In reality, some young firms may not have enough retained earnings and need external financing. Thus, dividend taxation affects their investment choices. This motivates our introduction of firm heterogeneity in the analysis. In our model, firms decide how much to invest and how to finance investment subject to equity issuance costs, collateral constraints, and capital adjustment costs. When making financing decisions, firms decide whether to use internal funds, debt, or external equity. In any period, there is a cross sectional distribution of firms that have different behaviors. Firms are forward-looking and have perfect foresight about future course of tax policies.

We focus on the dynamic effects of dividend and capital gains tax policies only, holding other taxes fixed. We use our model to provide a quantitative evaluation of the 2003 dividend and capital gains tax cuts prescribed by the JGTRRA, by numerically solving steady states and transitional dynamics. According to the JGTRRA, the capital gains tax rate is reduced from the previous 20 percent level for individuals in the top four tax brackets (facing marginal tax rates of 25, 28, 33 and 35 percent) to 15 percent. It is reduced from the previous 10 percent for individuals in the lower two tax brackets (facing marginal tax rates of 10 and 15 percent) to 5 percent. In addition, dividends are taxed at the same rate as capital gains, while they were taxed as ordinary income before 2003. In particular, dividends are taxed at the 15 percent rate for individuals in the top four tax brackets. This tax reform was first proposed by the Bush administration in January 2003 and was signed into law in May 2003. The original proposal put forward by President Bush was eventually dropped and replaced by a simpler version. Whether or not the final version would be passed was quite uncertain before May 2003, and thus we view the 2003 dividend tax cuts as largely unexpected. ${ }^{2}$

We find that the economic effects of the unexpected dividend and capital gains tax cuts are quite different, depending on whether these tax cuts are permanent or temporary. When the tax cuts are permanent, aggregate capital, investment, consumption, output, labor, and total factor productivity (TFP) all increase in the steady state. In addition, aggregate dividend payments and equity issuance also increase in the steady state. During the transition phase, aggregate capital increases monotonically over time. Aggregate investment rises on impact, but aggregate consumption falls on impact. By contrast, when the dividend and capital gains tax cuts are unexpected and temporary, as was likely the case in 2003, the steady state does not change. But aggregate investment decreases and aggregate dividend payments increase, during the periods when the tax cuts are implemented. In addition, aggregate output rises temporarily in the short run due to the increase in labor and the positive capital reallocation effect, measured by the temporary increase in TFP. When the tax cuts expire, investment surges and dividend payments fall. Our calibrated baseline model without debt financing predicts that the 2003 dividend and capital gains tax cuts may reduce aggregate investment by about 11 percent relative to the initial steady-state level during the transition phase.

Our analysis is in the spirit of Abel (1982), Auerbach (1989), Auerbach and Hines (1987), and Auerbach and Kotlikoff (1987), who analyze the dynamic effects of permanent and temporary corporate tax changes. Existing literature lacks a similar analysis of dividend tax policy. Such an analysis is important for understanding the 2003 dividend and capital gains tax cuts. Gourio and Miao (2010), Korinek and Stiglitz (2009), and McGrattan and Prescott (2005) study related theoretical issues. ${ }^{3}$ Korinek and Stiglitz (2009) obtain some results qualitatively similar to ours. ${ }^{4}$ But they do not provide a quantitative general equilibrium analysis. They also do not consider capital adjustment costs, debt financing, and taxes on corporate income and capital gains, that are important for firms' investment and financial policies. In addition, a firm's capital stock is equal to its investment in their model and hence their model cannot deliver a capital reallocation effect of a dividend tax cut.

In a general equilibrium growth model, McGrattan and Prescott (2005) show that permanent changes in the effective marginal tax rate on corporate distributions affect equity value, but not the capital-output ratio. As in Bradford (1981), they do not distinguish between dividends and repurchases by assuming that a flat tax rate is applied to the total corporate distributions. In this case, the representative firm's objective function is affected by a constant multiplicative factor in the presence of dividend taxation. Their model is consistent with the "new view" of dividend taxation in the public finance literature (e.g., Auerbach, 1979; Bradford, 1981, and King, 1977). We show that their result does not hold true when firms are subject to differential dividend and capital gains taxation and when there is firm heterogeneity in productivity (also see Gourio and Miao, 2010). In particular, we show that a temporary dividend tax cut and a temporary capital gains tax cut may have opposite effects during the transition phase in our model.

Our model differs from the existing literature in two main respects. ${ }^{5}$ First, most existing studies analyze a single firm's decision problem in partial equilibrium. These studies ignore firm heterogeneity which may be important for understanding the economic effects of dividend taxation, as emphasized by the theoretical study of Gourio and Miao (2010) and the empirical study of Auerbach and Hassett (2003). Second, most existing studies focus on the effects of permanent dividend

\footnotetext{
2 House and Shapiro (2006) also argue that the tax cuts were largely unexpected. In particular, these tax cuts were not part of the 2001 election platform.

3 Sinn (1991) lays out a model of the effects of dividend taxation in which firms go through different phases from immature to mature. But he does not study quantitative effects of tax changes.

4 In Sections 3.2 and 3.3, we will provide more detailed comparisons of our results and theirs.

5 See Auerbach (2002), Gordon and Dietz (2006), or Poterba and Summers (1985) for surveys.
} 
tax changes. However, the 2003 dividend tax cuts may be temporary. Gourio and Miao (2010) analyze the long-run effect of a permanent dividend and capital gains tax cut. We extend Gourio and Miao (2010) by studying the transitional dynamics for the case of a permanent or temporary tax cut. We also extend Gourio and Miao (2010) by endogenizing firms' choices between debt financing and equity financing.

The remainder of the paper proceeds as follows: Section 2 sets up a baseline model without debt financing. Section 3 provides quantitative results based on this baseline model. Section 4 extends the baseline model to incorporate debt financing. Section 5 concludes. Appendices A.1 and A.2 provide the numerical method for the baseline model.

\section{Baseline model}

In order to isolate the effect of debt financing, we start with a baseline model without debt. The model economy consists of a representative household, a continuum of firms with a unit mass, and a government. Time is discrete and denoted by $t=0,1,2, \ldots$. Assume that there is no aggregate uncertainty and that firms face idiosyncratic productivity shocks. By a law of large numbers, all aggregate quantities and prices are deterministic over time, although each firm still is exposed to idiosyncratic uncertainty.

In order to study transitional dynamics in response to dividend and capital gains tax cuts in a parsimonious and transparent way, we consider a simple tax system in which dividend tax rate $\tau_{t}^{d}$ and capital gains tax rate $\tau_{t}^{g}$ may change over time, while corporate tax rate $\tau^{c}$ and labor and interest income tax rate $\tau^{i}$ are constant over time. In addition, we assume that lump-sum taxes or transfers are available and that capital gains taxes are based on accrual rather than realization. ${ }^{6}$

\subsection{Firms}

Firms are ex ante identical and are subject to idiosyncratic productivity shocks. They differ ex post in that they may experience different histories of productivity shocks. Assume that these shocks are generated by a Markov process with transition function $Q$.

Firms combine labor and capital to produce output according to the production function $y_{t}=F\left(k_{t}, l_{t} ; z_{t}\right)$, where $k_{t}, l_{t}$, and $z_{t}$ denote capital, labor, and productivity, respectively. Assume that $F(\cdot)$ is strictly increasing, strictly concave in the first two arguments, and satisfies the usual Inada conditions. We can then derive the operating profit function $\pi\left(k_{t}, z_{t} ; w_{t}\right)$ by solving the following static labor choice problem:

$$
\pi\left(k_{t}, z_{t} ; w_{t}\right)=\max _{l_{t}}\left\{F\left(k_{t}, l_{t} ; z_{t}\right)-w_{t} l_{t}\right\},
$$

where $w_{t}$ denotes the wage rate. This problem gives the labor demand function $l\left(k_{t}, z_{t} ; w_{t}\right)$ and the output supply $y_{t}\left(k_{t}, z_{t}\right)=F\left(k_{t}, l\left(k_{t}, z_{t} ; w_{t}\right) ; z_{t}\right)$.

When a firm makes investment $x_{t}$ to increase its capital stock, its capital stock $k_{t+1}$ in the next period satisfies:

$$
k_{t+1}=(1-\delta) k_{t}+x_{t}, \quad k_{0} \text { given, }
$$

where $\delta \in(0,1)$ denotes the depreciation rate. Investment incurs adjustment costs. For simplicity, we consider the quadratic adjustment cost function, $\psi x_{t}^{2} /\left(2 k_{t}\right)$, widely used in the empirical investment literature.

Firms use internal or external funds to finance investments. In the baseline model, we assume that firms can access to external equity markets only. In Section 4, we extend this model to allow firms to use debt financing as well. Raising new equity is costly due to information asymmetry or transactions costs. Following Chen and Ritter (2000), Gomes (2001) and Hennessy and Whited (2005), we assume that for each dollar of raised new equity, there is a flotation cost $\lambda$.

A firm's problem is to choose investment and financial policies so as to maximize its equity value. In order to formulate this decision problem, we first derive a typical firm's equity valuation equation. Let the ex-dividend equity value be $P_{t}$ at date $t$. The following no arbitrage equation must hold ${ }^{7}$ :

$$
r_{t+1}^{e}=\frac{1}{P_{t}} E_{t}\left[\left(1-\tau_{t+1}^{d}\right) d_{t+1}+\left(1-\tau_{t+1}^{g}\right)\left(P_{t+1}-P_{t}-\left(1+\lambda \mathbf{1}_{s_{t+1}>0}\right) s_{t+1}\right)\right]
$$

where $r_{t+1}^{e}$ denotes the required after-tax rate of return on equity between period $t$ and period $t+1, d_{t+1}$ is the firm's period $t+1$ dividend payments, and $s_{t+1}$ denotes the value of equity newly issued (repurchases) in period $t+1$ if $s_{t+1} \geqslant(<) 0$. Note that $\mathbf{1}_{s_{t+1}>0}$ is an indicator function, taking the value 1 if $s_{t+1}>0$, and zero, otherwise. In addition, $E_{t}$ denotes the conditional expectation operator with respect to the distribution induced by the idiosyncratic productivity shocks.

\footnotetext{
6 In the US, capital gains are taxed on realization rather than on accrual. Incorporating a realization-based capital gains tax would complicate our analysis significantly.

7 According to the US tax system, capital losses are tax deductible within some limit. For tractability, we ignore this limit in our model.
} 
Because we assume there is no aggregate uncertainty, there is no risk premium for equity. Thus, no arbitrage implies that the required rate of return on equity is equal to the after tax interest rate: $r_{t+1}^{e}=\left(1-\tau^{i}\right) r_{t+1}$. It follows that we can rewrite Eq. (3) as:

$$
V_{t}=\frac{1-\tau_{t}^{d}}{1-\tau_{t}^{g}} d_{t}-\left(1+\lambda \mathbf{1}_{s_{t}>0}\right) s_{t}+\frac{E_{t} V_{t+1}}{1+r_{t+1}\left(1-\tau^{i}\right) /\left(1-\tau_{t+1}^{g}\right)},
$$

where we define the cum-dividend equity value as:

$$
V_{t}=P_{t}-\left(1+\lambda \mathbf{1}_{\left.s_{t}>0\right)}\right) s_{t}+\frac{1-\tau_{t}^{d}}{1-\tau_{t}^{g}} d_{t}
$$

We may solve this equation forward and impose a no bubble condition to obtain equity value in any period $t \geqslant 0$ :

$$
V_{t}=E_{t} \sum_{j=0}^{\infty} \frac{1}{R_{t, t+j}}\left(\frac{1-\tau_{t+j}^{d}}{1-\tau_{t+j}^{g}} d_{t+j}-\left(1+\lambda \mathbf{1}_{s_{t+j}>0}\right) s_{t+j}\right),
$$

where $R_{t, t}=1$ and

$$
R_{t, t+j}=\prod_{s=0}^{j-1}\left[1+r_{t+s+1}\left(1-\tau^{i}\right) /\left(1-\tau_{t+s+1}^{g}\right)\right] .
$$

The firm chooses investment and financial policies $\left(x_{t}, k_{t+1}, s_{t}, d_{t}\right)$ to maximize its equity value (5) subject to the capital accumulation equation (2) and the following constraints:

$$
\begin{aligned}
& x_{t}+\frac{\psi x_{t}^{2}}{2 k_{t}}+d_{t}=\left(1-\tau^{c}\right) \pi\left(k_{t}, z_{t} ; w_{t}\right)+\tau^{c} \delta k_{t}+s_{t}, \\
& d_{t} \geqslant 0 \\
& s_{t} \geqslant-\bar{s},
\end{aligned}
$$

for all $t \geqslant 0$.

Eq. (7) describes the flow of funds condition for the firm. The source of funds consists of after-tax profits and new equity issuance. The use of funds consists of investment expenditure and dividend payments. Dividend payments cannot be negative. We thus impose constraint (8). We do not consider other constraints on dividend payments as in Auerbach (2002) and Poterba and Summers (1983). There may be effective restriction on share repurchases. In the United States, share repurchases are allowed. However, regular repurchases may lead the IRS to treat repurchases as dividends. Also, repurchases may be costly. These costs may be associated with asymmetric information (see, e.g., Brennan and Thakor, 1990). To reflect the regulatory constraint, we follow Poterba and Summers (1985) to impose a constraint that share repurchases are bounded by some maximal amount $\bar{s}>0$.

The term $\left(1-\tau_{t+j}^{d}\right) /\left(1-\tau_{t+j}^{g}\right)$ represents the tax wedge between internal finance and external equity finance. It is straightforward from Eq. (5) to show that, when $\lambda=0$ and $\tau_{t+j}^{d}=\tau_{t+j}^{g}$ for all $t$ and $j$, the Miller and Modigliani dividend policy irrelevance theorem holds (Miller and Modigliani, 1961). In particular, a firm's investment and payout policies are independent. In addition, dividend payments and share repurchases (or equity issuance) are indeterminate because they do not matter for firm value and investment policy.

However, when $\tau_{t+j}^{d}>\tau_{t+j}^{g}$ and $\lambda>0$, five cases may happen in the firm's optimization problem. Each case corresponds to a different finance regime:

1. The equity issuance regime: $d_{t}=0, s_{t}>0$. In this regime, the firm does not pay dividends but issues new equity. This firm has a relatively small capital stock and relatively high productivity. Hence, it decides to raise new equity to finance investment. This is typically the case for young and small firms.

2. Internal growth regime: $d_{t}=0, s_{t}=0$. In this regime, the firm does not pay dividends. In addition, it does not buy back shares or issue new equity.

3. The equity buy-back regime: $d_{t}=0,-\bar{s}<s_{t}<0$. In this regime, the firm does not pay dividends, but buys back equity. In addition, the share repurchase constraint (9) does not bind.

4. The dividend-constrained regime: $d_{t}=0, s_{t}=-\bar{s}$. In this regime, the firm does not pay dividends, but buys back equity as much as possible so that the share repurchase constraint (9) binds.

5. The dividend-paying regime: $d_{t}>0, s_{t}=-\bar{s}$. In this regime, the firm exhausts the share repurchase opportunity so that the constraint (9) binds. In addition, the firm also distributes dividends. This firm is mature, less productive, and has a large capital stock. 
The presence of equity issuance costs $(\lambda>0)$ generates a kink in equity value. As a result, there is a nontrivial region of states in which the firm does not buy back or issue equity $\left(s_{t}=0\right)$. Only when the firm is sufficiently productive will it pay the issuance costs to raise new equity to finance investment. Note that the case with $d_{t}>0$ and $s_{t}>-\bar{s}$ cannot happen at optimum. If it happened, the firm could reduce its tax burden by reducing dividends and repurchasing shares.

The effect of dividend taxation on a firm's investment policy depends on the finance regimes in two adjacent periods. With firm heterogeneity, in any period there is a cross section of firms that may lie in different finance regimes. Thus, dividend taxation has different effects on firms in different regimes. This heterogeneity is crucial for our analysis for two reasons. First, if all firms are identical, then all these firms will lie in only one of the above five finance regimes. But in the data, at any point in time some firms issue equity and some firms pay out dividends so that there are some firms in each regime (see Auerbach and Hassett, 2003 and Gourio and Miao, 2010). Second, Gourio and Miao (2010) show that a permanent dividend tax cut does not affect long-run capital stock in a model without firm heterogeneity, while it raises long-run capital stock when there is firm heterogeneity.

\subsection{Household}

The representative household derives utility from consumption and leisure according to the standard time-additive utility function:

$$
\sum_{t=0}^{\infty} \beta^{t} U\left(C_{t}, N_{t}\right)
$$

where $\beta$ is the discount factor, $C_{t}$ denotes consumption, $N_{t}$ denotes labor supply, and $U$ satisfies $U_{1}>0, U_{11}<0, U_{2}<0$, $U_{22}<0$, and the Inada conditions.

The household owns all firms and trades firms' shares. In addition, the household also trades a risk-free bond in zero net supply. It pays dividend taxes, personal income taxes, and capital gains taxes. In order to write its budget constraint, we must aggregate all firms' quantities. To this end, we let $\mu_{t}$ denote the cross sectional distribution of firms over the state $(k, z)$ in period $t$. The budget constraint is then given by:

$$
\begin{aligned}
C_{t} & +\int P_{t} \theta_{t+1} d \mu_{t}+b_{t+1}-\left(1+\left(1-\tau^{i}\right) r_{t}\right) b_{t}-T_{t}-\left(1-\tau^{i}\right) w_{t} N_{t} \\
& =\int\left[\left(1-\tau_{t}^{d}\right) d_{t}+P_{t}-\left(1+\lambda \mathbf{1}_{s_{t}>0}\right) s_{t}-\tau_{t}^{g}\left(P_{t}-P_{t-1}-\left(1+\lambda \mathbf{1}_{s_{t}>0}\right) s_{t}\right)\right] \theta_{t} d \mu_{t-1},
\end{aligned}
$$

where $\theta_{t}$ denotes the shares owned by the household, $b_{t}$ denotes bond holdings, $r_{t}$ denotes the interest rate, and $T_{t}$ denotes the transfer from the government. In equilibrium $\theta_{t}=1$ and $b_{t}=0$ for all $t$.

First-order conditions with respect to $N_{t}, \theta_{t+1}$ and $b_{t+1}$ imply that

$$
\begin{aligned}
& \frac{-U_{2}\left(C_{t}, N_{t}\right)}{U_{1}\left(C_{t}, N_{t}\right)}=\left(1-\tau^{i}\right) w_{t}, \\
& U_{1}\left(C_{t}, N_{t}\right)=\beta U_{1}\left(C_{t+1}, N_{t+1}\right)\left(1+\left(1-\tau^{i}\right) r_{t+1}\right), \\
& P_{t} U_{1}\left(C_{t}, N_{t}\right)= \beta U_{1}\left(C_{t+1}, N_{t+1}\right) E_{t}\left[\left(1-\tau_{t+1}^{d}\right) d_{t+1}+P_{t+1}-\left(1+\lambda \mathbf{1}_{s_{t+1}>0}\right) s_{t+1}\right. \\
&\left.-\tau_{t+1}^{g}\left(P_{t+1}-P_{t}-\left(1+\lambda \mathbf{1}_{s_{t+1}>0}\right) s_{t+1}\right)\right] .
\end{aligned}
$$

Note that in the absence of aggregate uncertainty, there is no risk premium and thus the preceding equations imply that the required rate of return on equity is equal to the after tax interest rate. As a result, we obtain Eqs. (3) and (4).

\subsection{Government}

As a starting point, we consider a simple government budget rule in which tax revenues collected by the government are rebated to the household in a lump-sum manner. In addition, we abstract away from government spending. Because we allow for lump-sum transfers, there is no loss of generality in assuming that the government budget is balanced in each period.

\subsection{Equilibrium}

Conditional on aggregate states, firms can be differentiated by their capital stock and idiosyncratic productivity shocks. We use the cross sectional distribution of firms $\mu_{t}$ to conduct aggregation based on each firm's behavior derived in Section 2.1. This distribution is over firm-specific capital stock and idiosyncratic productivity shocks $(k, z)$. Its law of motion satisfies:

$$
\mu_{t+1}(A \times B)=\int \mathbf{1}_{g_{t}(k, z) \in A} Q(z, B) \mu_{t}(d k, d z),
$$


where $\mathbf{1}$ is an indicator function, $g_{t}$ is the policy function for the capital stock such that $k_{t+1}=g_{t}\left(k_{t}, z_{t}\right)$, and $A$ and $B$ are measurable sets. We can then define a competitive equilibrium in the usual manner. In particular, each firm optimizes, the household optimizes, and aggregate markets clear.

The market clearing condition for labor is given by:

$$
N_{t}=\int l\left(k, z ; w_{t}\right) \mu_{t}(d k, d z)
$$

where $l\left(k, z ; w_{t}\right)$ is a firm's static labor demand derived from (1). The resource constraint is given by:

$$
C_{t}+\int x_{t}(k, z) \mu_{t}(d k, d z)+\int \frac{\psi x_{t}(k, z)^{2}}{2 k} \mu_{t}(d k, d z)+\lambda \int_{s_{t}>0} s_{t}(k, z) \mu_{t}(d k, d z)=\int y_{t}(k, z) \mu_{t}(d k, d z),
$$

where $x_{t}(k, z), s_{t}(k, z)$, and $y_{t}(k, z)$ are a firm's optimal investment and equity issuance/repurchase policies and output supply derived in Section 2.1, respectively.

\section{Results}

We solve our model numerically and conduct simulations. Briefly speaking, we first solve the initial steady state before the dividend tax reform and then solve the final steady state after the dividend tax reform. We finally use a shooting algorithm to solve the transition path connecting the two steady states. We provide a detailed description of our numerical method in Appendix A.

\subsection{Parameter values}

We calibrate our model at the annual frequency and match model moments in the initial steady state with those obtained from the COMPUSTAT database. ${ }^{8}$ The sample period ranges from 1988 to 2002, which corresponds to the period before the 2003 dividend tax cut. We set the tax rates in the initial steady state to correspond to the US federal statutory rates in 2002 before the tax reform.

We consider the utility function:

$$
U(C, N)=\ln (C)-\frac{h N^{2}}{2},
$$

where $h>0$ is the weight on leisure. This utility function has a unitary Frisch elasticity of labor supply, which is reasonable for macro models as argued by Hall (2009). We choose the discount factor $\beta$ such that the steady-state interest rate is equal to 0.04 using Eq. (12). We choose the parameter $h$ to match the equilibrium labor supply of 0.3 , which is the average fraction of time spent on market work.

We choose the Cobb-Douglas production function with decreasing returns to scale, $F(k, l ; z)=z k^{\alpha_{k}} l^{\alpha_{l}}$, where $0<\alpha_{k}$, $\alpha_{l}<1$ and $\alpha_{k}+\alpha_{l}<1$. We assume that the productivity shock follows the process:

$$
\ln z_{t}=\rho \ln z_{t-1}+\varepsilon_{t}
$$

where $\varepsilon_{t}$ is i.i.d. and normally distributed with mean zero and variance $\sigma^{2}$. We set $\rho$ and $\sigma$ to be the estimates in Gourio and Miao (2010). We choose the depreciation rate to match the aggregate investment-capital ratio, which is equal to 0.095 according to the National Income and Product Accounts.

We follow Gomes (2001) and set the equity issuance cost $\lambda=0.028$. We choose the limit on share repurchase $\bar{s}$ such that share repurchases account for 25 percent of earnings, which is close to the estimate documented by Allen and Michaely (2003). Finally, we choose the adjustment cost parameter $\psi$ to match the cross sectional volatility (standard deviation) of the investment rate in the data, which is 0.156. A model without adjustment costs would deliver a very high value of the cross sectional volatility of the investment rate, which is inconsistent with the data.

In summary, we list the baseline parameter values in Table 1 . The main difference between this calibration and that in Gourio and Miao (2010) is that here we introduce equity issuance costs and share repurchases in the baseline model. We also re-calibrate the adjustment cost parameter accordingly to match the volatility of the investment rate.

We assume that the economy prior to period 1 is in the initial steady state with parameter values given in Table 1 . We then study the economy's responses to dividend and capital gains tax cuts. We use our model to provide a quantitative evaluation of the impact of the 2003 dividend and capital gains tax cuts. After these tax cuts, the dividend and capital gains tax rates are reduced from the levels given in Table 1 to the same 15 percent level. The 2003 dividend and capital gains tax cuts were generally viewed as temporary, though their duration was uncertain. We study both cases of temporary and permanent tax cuts in order to highlight the difference between these two cases. In addition, in all the policy experiments below, we assume that tax cuts are unexpected, since this seems the relevant case, as discussed in Section 1.9

\footnotetext{
8 Our calibration strategy follows from Gourio and Miao (2010) closely. We refer the reader to that paper for more details.

9 We can easily extend our analysis to the case of expected tax changes.
} 
Table 1

Baseline parameter values.

\begin{tabular}{lll}
\hline & Parameter & Value \\
\hline Corporate income tax & $\tau^{c}$ & 0.340 \\
Personal income tax & $\tau^{i}$ & 0.250 \\
Dividend tax & $\tau^{d}$ & 0.250 \\
Capital gain tax & $\tau^{g}$ & 0.200 \\
Exponent on capital & $\alpha_{k}$ & 0.311 \\
Exponent on labor & $\alpha_{l}$ & 0.650 \\
Shock persistence & $\rho$ & 0.767 \\
Shock standard deviation & $\sigma$ & 0.211 \\
Depreciation rate & $\delta$ & 0.095 \\
Discount factor & $\beta$ & 0.971 \\
Weight on leisure & $h$ & 6.616 \\
Adjustment cost & $\psi$ & 0.890 \\
Equity issuance cost & $\lambda$ & 0.028 \\
Share repurchase limit & $\bar{s}$ & 0.040 \\
\hline
\end{tabular}

K

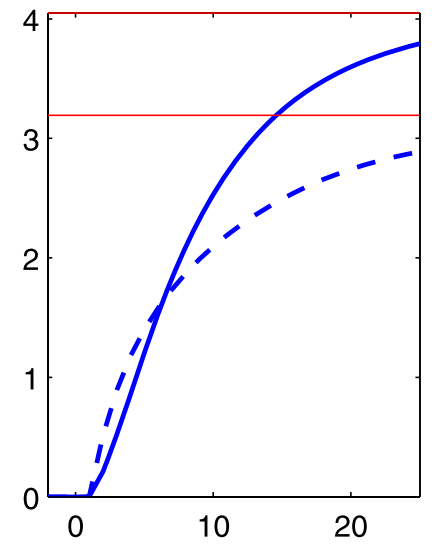

N

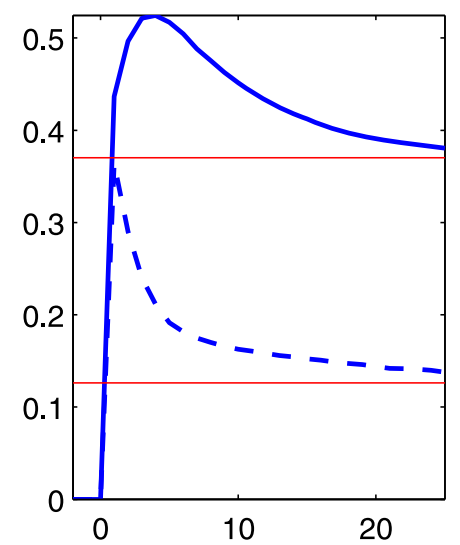

Y

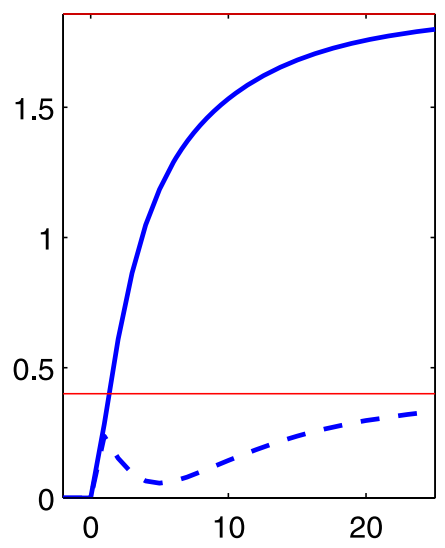

I

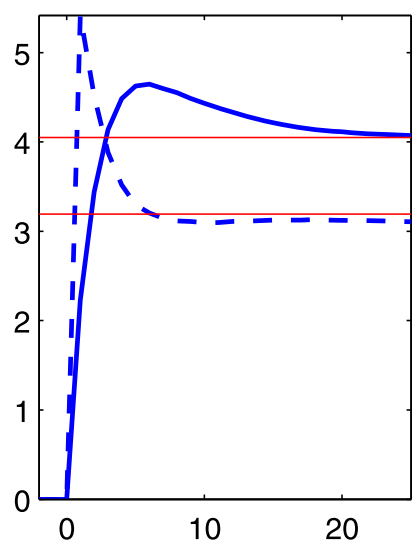

C

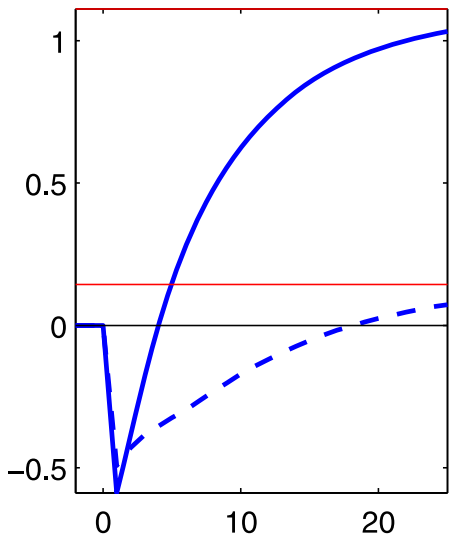

TFP

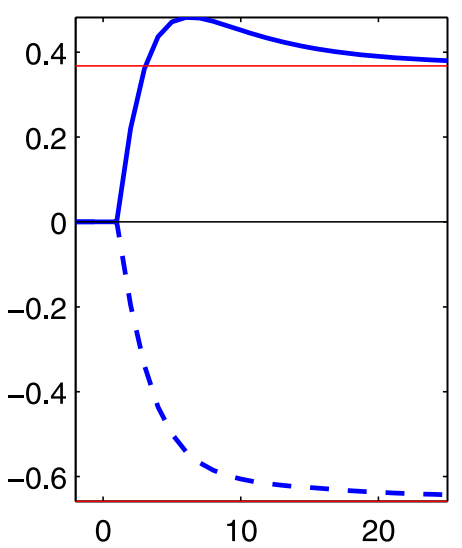

Fig. 1. Impact of unexpected permanent tax cuts in the baseline model. The economy before period 1 is at the initial steady state with parameter values given in Table 1 . The solid lines plot the responses of capital $(K)$, output $(Y)$, consumption $(C)$, labor $(N)$, investment $(I)$, and TFP to the unexpected permanent cuts of the dividend tax rate from 0.25 to 0.15 and of the capital gains tax rate from 0.20 to 0.15 . The dashed lines plot the case when only the capital gains tax rate is reduced from 0.20 to 0.15 . In each panel, the horizontal axis measures time period, and the vertical axis measures percentage deviation from the initial steady state before the tax cuts.

\subsection{Unexpected permanent dividend and capital gains tax cuts}

We start with the case in which the dividend and capital gains tax cuts are permanent. These tax cuts are unexpected in period 1 but are known to be permanent as soon as they occur. To separate out the effects of changes in the dividend tax rate and changes in the capital gains tax rate, we also study the case in which only the capital gains tax rate changes holding the dividend tax rate fixed.

First, we conduct the policy experiment in which only the capital gains tax rate is reduced from 0.2 to 0.15 permanently. The dashed lines in Fig. 1 present the transitional dynamics of capital, investment, output, consumption, labor, and total fac- 

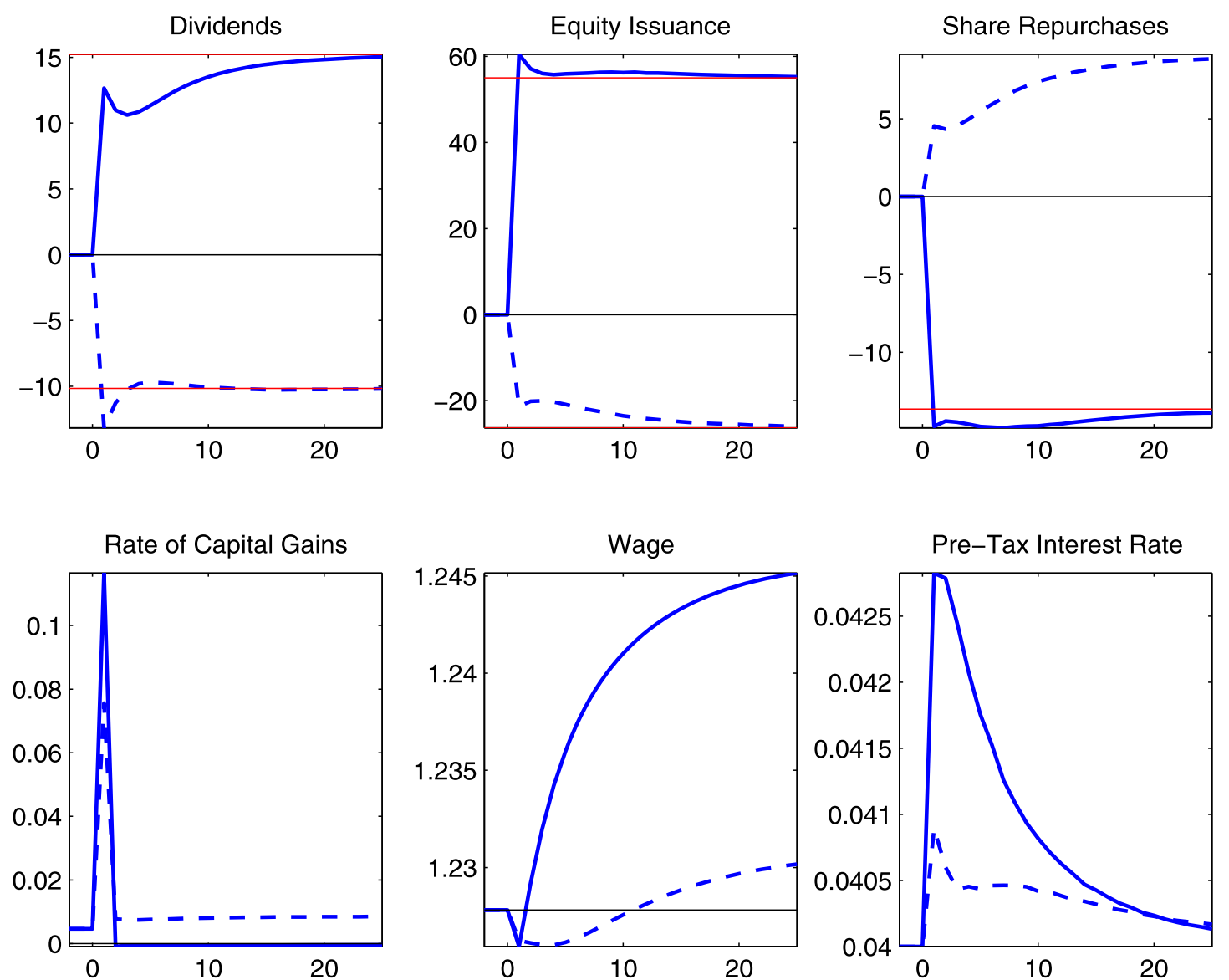

Fig. 2. Impact of unexpected permanent tax cuts in the baseline model. The economy before period 1 is at the initial steady state with parameter values given in Table 1 . The solid lines plot the responses of aggregate dividend payments, equity issuance, share repurchases, the rate of capital gains, wage and the pre-tax interest rate to the unexpected permanent cuts of the dividend tax rate from 0.25 to 0.15 and of the capital gains tax rate from 0.20 to 0.15 . The dashed lines plot the case when only capital gains tax rate is reduced. In each panel, the horizontal axis measures the time period. In the top three panels, the vertical axes measure the percentage deviation from the initial steady state before the tax cuts. In the bottom three panels, the vertical axes measure the actual simulated values after the tax cuts.

tor productivity (TFP). ${ }^{10}$ After about 40 periods the economy converges to the new steady state. The steady-state aggregate capital stock, output, consumption, labor and investment increase by about 3.2, 0.4, 0.2, 0.1 , and 3.2 percent, respectively. This result reflects the fact that the capital gains tax cuts reduce the user cost of capital and hence benefit the economy in the long run.

In the short run, the aggregate capital stock is predetermined, but aggregate investment jumps up. In addition, the pre-tax interest rate rises initially to induce the household to consume less and save more for investment, as illustrated in Fig. 2. Because of the presence of convex capital adjustment costs, capital rises monotonically and smoothly to the new steady state, but investment rises on impact and then gradually falls to the new steady-state level. Consumption falls initially and then rises to the new steady-state level. As a result, the representative household increases labor supply initially and then reduces labor supply. Because the aggregate labor demand does not change on impact (since the capital stock and productivity are fixed), the equilibrium wage falls initially and then gradually rises to the new steady-state level, as illustrated in Fig. 2.

As presented by the dashed lines in Fig. 2, the reduction in the capital gains tax rate induces firms to reduce dividend payments and equity issuance, but to increase share repurchases. This raises the rate of capital gains, measured by

$$
\frac{\int\left(P_{t+1}-P_{t}-\left(1+\lambda \mathbf{1}_{s_{t+1}>0}\right) s_{t+1}\right) d \mu_{t}}{\int P_{t} d \mu_{t}},
$$

10 As in Gourio and Miao (2010), we define TFP at time $t$ as

$$
\frac{Y_{t}}{K_{t}^{\alpha_{k}} L_{t}^{\alpha_{l}}}=\frac{\left[\int\left(z k^{\alpha_{k}}\right)^{\frac{1}{1-\alpha_{l}}} \mu_{t}(d k, d z)\right]^{1-\alpha_{l}}}{\left[\int k \mu_{t}(d k, d z)\right]^{\alpha_{k}}},
$$

where $Y_{t}, K_{t}$, and $L_{t}$ are aggregate output, capital stock, and labor demand, respectively. We have used the Cobb-Douglas production function to compute TFP. This measure corresponds to the aggregate TFP that a macroeconomist would compute given measured output, capital and labor. 
Panel A: Finance Regimes (Capital Gains Tax Cuts Only)

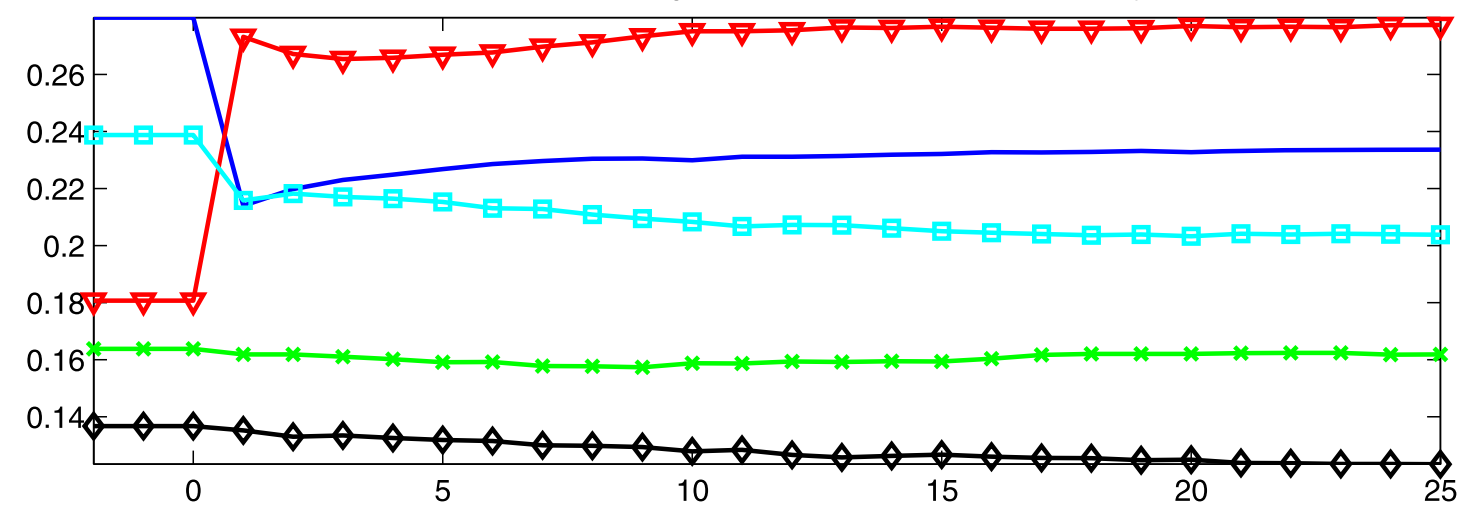

Panel B: Finance Regimes (Dividend and Capital Gains Tax Cuts)

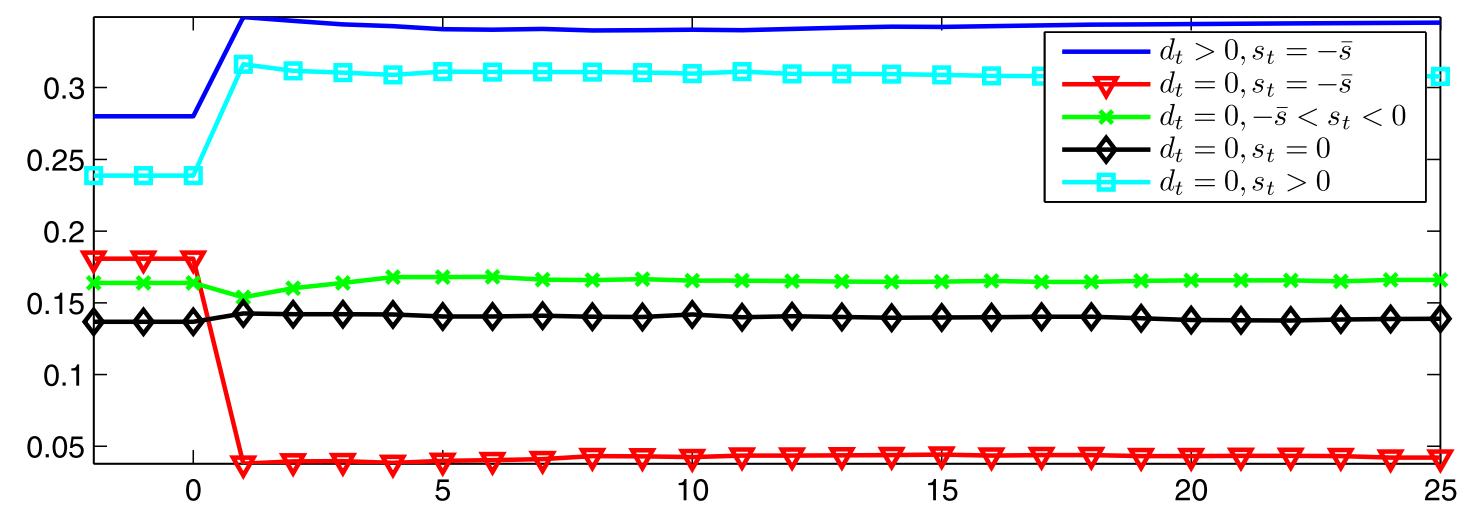

Fig. 3. Impact of unexpected permanent tax cuts in the baseline model. The economy before period 1 is at the initial steady state with parameter values given in Table 1. Panel A plots the evolution of the finance regimes in response to the unexpected permanent cuts of the dividend tax rate from 0.25 to 0.15 and of the capital gains tax rate from 0.20 to 0.15 . Panel B plots the case when only the capital gains tax rate is reduced. The vertical axes measure the shares of firms in each finance regime.

from the initial steady-state level of 0.5 percent immediately to about 8 percent and then reduces to the new steady-state level of about 0.6 percent. In the initial steady state, aggregate equity value is constant. The 0.5 percent rate of capital gains reflects the fact that firms repurchase shares $\left(s_{t+1}<0\right)$ on average. In the new steady state, although aggregate equity value is still constant, firms buy back more equity, leading to a small increase in the rate of capital gains. The increase in the capital gains on impact of about 8 percent reflects a jump in the value of the stock market, as firms' tax-adjusted discount rates $R_{t, t+j}$ defined in (6) fall.

Interestingly, Fig. 1 shows that the steady-state TFP decreases by about 0.65 percent after the capital gains tax cuts. The intuition can be gained from the evolution of the finance regimes presented in panel A of Fig. 3. We find that, after the capital gains tax cuts, more firms move to the dividend constrained regime $\left(d_{t}=0\right.$ and $\left.s_{t}=-\bar{s}\right)$ and less firms stay in the dividend-paying regime $\left(d_{t}>0\right.$ and $\left.s_{t}=-\bar{s}\right)$, because the capital gains tax cuts encourage firms to substitute dividends for equity buy-back. In addition, there are less firms in the equity issuance regime $\left(s_{t}>0\right.$ and $\left.d_{t}=0\right)$. Because more firms are constrained, capital cannot be reallocated to more productive firms from less productive firms, leading to a decrease in the TFP.

Next, we conduct the experiment in which both the capital gains and dividend tax rates are reduced to the 15 percent level permanently. The economy's responses are presented by the solid lines in Figs. 1 and 2 . We find that the short-run increase in investment is smaller because firms use some resources to pay out more dividends. But the long-run effects on real quantities are larger due to the additional reallocation effect of the dividend tax cuts. In particular, the steady-state TFP rises by about 0.36 percent, in contrast to the case of the capital gains tax cuts only. The intuition comes from the firms' payout behavior and the changes in the finance regimes. When both the capital gains and dividend tax rates are reduced, firms increase dividend payments and equity issuance, but reduce share repurchases. Aggregate dividends and equity issuance rise by about 12.5 and 60 percent on impact, respectively. In the new steady state, they rise by about 15 and 55 percent, respectively. In addition, less firms are in the dividend-constrained regime $\left(d_{t}=0\right.$ and $\left.s_{t}=-\bar{s}\right)$ and more firms are in the equity issuance regime $\left(s_{t}>0\right.$ and $\left.d_{t}=0\right)$, as illustrated in panel B of Fig. 3 . Thus, the dividend tax cuts generate efficient reallocation of capital from less productive (mature) firms to more productive (immature) firms. ${ }^{11}$

\footnotetext{
11 See Restuccia and Rogerson (2008) and Buera and Shin (2009) for related analysis where changes in reallocation friction lead to increased aggregate productivity.
} 
As in our paper, Korinek and Stiglitz (2009) show that aggregate capital and output increase monotonically to their new steady-state levels following a permanent dividend tax cut (see Fig. 5 in their paper). However, unlike ours, their model does not incorporate capital depreciation and adjustment costs. Thus, the capital stock is equal to investment in their model. So they follow an identical transition path. In addition, they do not study the capital reallocation effect as measured by the change in TFP. They also do not study the effect of a capital gains tax cut.

Panel B of Fig. 3 also shows that more firms move to the dividend-paying regime $\left(d_{t}>0\right.$ and $\left.s_{t}=-\bar{s}\right)$ in response to the permanent dividend and capital gains tax cuts. Thus, these tax cuts generate not only an intensive margin effect by changing a firm's dividend payments, but also an extensive margin effect by changing the number dividend-paying firms. This result cannot be obtained from a representative firm model. Chetty and Saez (2005) find empirical evidence that the 2003 dividend and capital gains tax cuts had both intensive and extensive margin effects.

Fig. 2 also shows that, in response to the permanent dividends and capital gains tax cuts, the rate of capital gains rises to about 12 percent on impact and then decreases to a number close to zero in the new steady state. The intuition is as follows. The permanent dividend and capital gains tax cuts raise equity value and hence capital gains on impact. These tax cuts also raise equity issuance, instead of raising share repurchases as in the case of the capital gains tax cuts only. The increased equity issuance dilutes equity and reduces capital gains. Our numerical experiment shows that the former effect dominates the latter in the initial period. The latter effect becomes large later on so that the rate of capital gains fall. In the new steady state, the net of aggregate equity issuance and share repurchases are close to zero and aggregate equity value is constant over time. As a result, the rate of capital gains is close to zero in the new steady state.

\subsection{Unexpected temporary dividend and capital gains tax cuts}

We now turn to the case of temporary dividend and capital gains tax cuts. The 2003 dividend and capital gains tax cuts were initially scheduled to expire in 2008, and were later extended through 2010. A further extension is uncertain. Thus, this tax policy is likely to be temporary and unexpected. Our simulations below show that a temporary dividend and capital gains tax cut has a surprising effect on the economy in the short to medium run. ${ }^{12}$

To simulate the transitional dynamics of the 2003 temporary tax cuts, we assume the economy in period 1 is in the initial steady state corresponding to the tax system before the tax cuts. The tax cuts are unexpectedly made in period 1 and last for 8 years. After 8 years, the dividend and capital gains tax rates revert back to their original levels. Consequently, the final steady state is identical to the initial steady state.

The solid lines in Fig. 4 present the transitional dynamics of capital, investment, output, consumption, labor, and TFP. In sharp contrast to Fig. 1 in the case of permanent tax cuts, investment jumps down in period 1 in response to the temporary tax cuts rather than jumping up. Investment continues to decrease until period 8 and falls by about 11 percent relative to its steady-state level in period 8. It jumps up by about 3 percent in period 9 and then gradually falls until it reaches its steady-state level. The intuition behind this result can be gained from Fig. 5 . In response to the dividend and capital gains tax cuts in period 1, firms pay more dividends, so they cut back investment. The initial rise in dividends is about 15 percent. Anticipating the dividend tax rate will revert back to its original higher level in period 9, firms respond by cutting back investment and paying out large dividends in period 8 , while they reduce dividend payments and raise investment in period 9. In particular, dividend payments rise by about 25 percent in period 8 and decrease by about 10 percent in period 9. To summarize, firms conduct intertemporal tax arbitrage by taking advantage of the temporary lower dividend taxes to pay out large dividends.

The decrease in capital in the short to medium run reflects a higher after-tax interest rate, as illustrated in Fig. 5. This higher interest rate leads to the rise of labor supply in the initial period by the intertemporal substitution effect. Thus, output also rises on impact because capital is predetermined. Because capital decreases until period 9, output also decreases until period 8 , but consumption increases until period 8 because of high interest rates. Consumption may rise by slightly more than 1 percent. In period 9, consumption and dividends drop, but investment and labor rise, because starting in period 9 the dividend tax rate rises to its original level permanently. After period 9, all variables gradually revert back to their steady-state values. Interestingly, TFP rises from periods 2 to 9 . The reason is that the cost wedge between internal and external funds is temporarily reduced from periods 1-8, yielding a positive reallocation effect. The increase in TFP also contributes to the initial increase in output.

To isolate the effect of the change in the dividend tax rate from that of the change in the capital gains tax rate, we present the transitional dynamics of real quantities using the dashed lines in Fig. 4 when only the capital gains tax rate changes holding the dividend tax rate fixed, as in Section 3.2. In this case, capital, investment, output, consumption, labor, and TFP follow almost opposite paths to those in the case of both dividend and capital gains tax cuts. Similarly to Section 3.2, the intuition comes from the firms' payout behavior. As illustrated in Fig. 5, the two cases deliver opposite transitional paths for aggregate dividends, equity issuance and share repurchases. Intuitively, the temporary decrease in the capital gains tax rate induces firms to make more investments in the short run. But the temporary decrease in the dividend tax rate induces firms to cut back investment in order to make large dividend payments in the short run. This effect is large enough so that the net effect of the dividend and capital gains tax cuts is to decrease investment in the short run.

12 Korinek and Stiglitz (2009) make a similar point theoretically in a more stylized setup. 


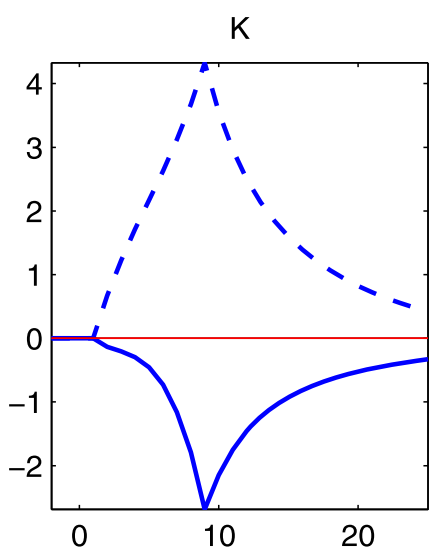

$\mathrm{N}$

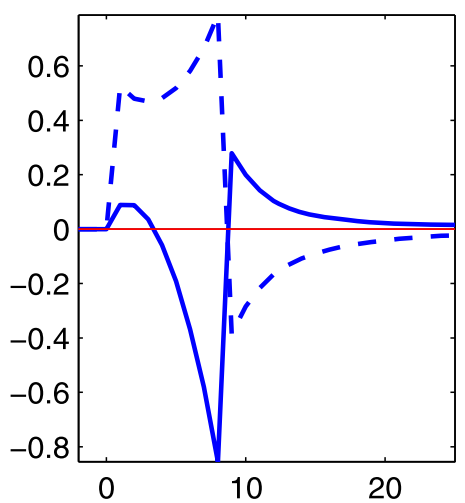

Y

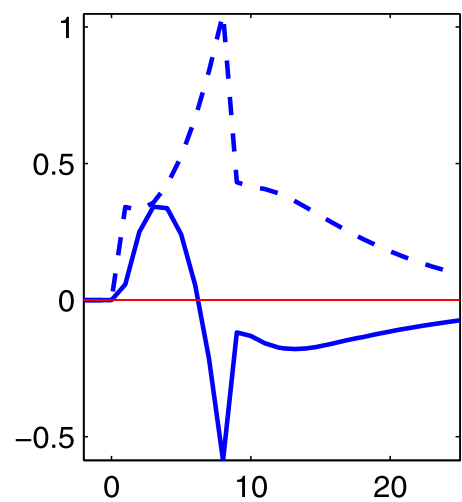

I

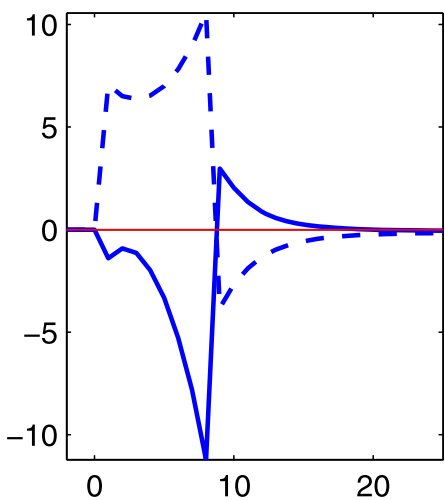

C

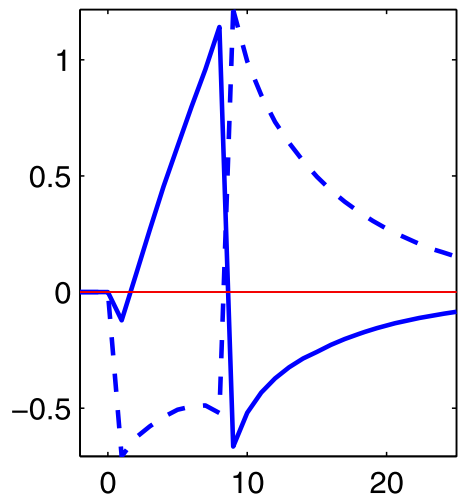

FP

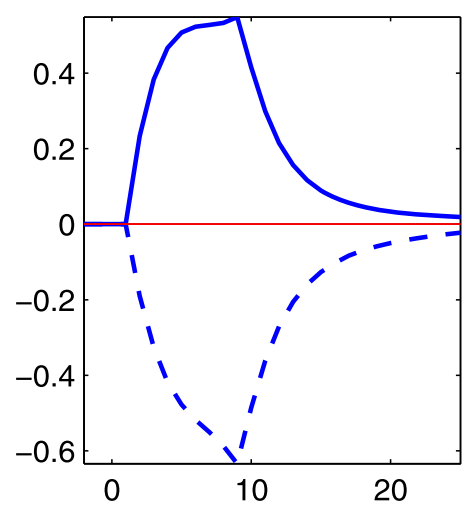

Fig. 4. Impact of unexpected temporary tax cuts in the baseline model. The economy before period 1 is at the initial steady state with parameter values given in Table 1 . The solid lines plot the responses of capital $(K)$, output $(Y)$, consumption $(C)$, labor $(N)$, investment $(I)$, and TFP to the unexpected temporary cuts of the dividend tax rate from 0.25 to 0.15 and of the capital gains tax rate from 0.20 to 0.15 . The tax cuts last from periods 1 to 8 . The dashed lines plot the case when only the capital gains tax rate is reduced. In each panel, the horizontal axis measures time period, and the vertical axis measures percentage deviation from the initial steady state before the tax cuts.

Fig. 5 also shows that the rate of capital gains rises from 0.5 percent to 9 percent in period 1 , but decreases to -2.1 percent in period 9 , in response to the temporary dividend and capital gains tax cuts. The initial rise in the rate of capital gains reflects the fact that equity value rises immediately. The fall of the rate of capital gains in period 9 reflects the fact that equity value drops in period 9 because starting from this period on dividends and capital gains tax rates revert back to their original higher levels. By contrast, in response to the temporary capital gains tax cuts only, the rate of capital gains rises by about 3 percent in period 9, rather than falling. The intuition is that firms reduce equity issuance and raise share repurchases in period 9 because they expect the capital gains tax rate will revert back to the initial higher level forever after period 9. The increase in share repurchases in period 9 raises capital gains.

Fig. 6 presents the transitional dynamics of the finance regimes. In response to the temporary capital gains tax cuts, the shares of firms in the dividend-paying regime $\left(d_{t}>0\right.$ and $\left.s_{t}=-\bar{s}\right)$ and the equity issuance regime $\left(d_{t}=0\right.$ and $\left.s_{t}>0\right)$ temporarily fall from periods $1-8$, but the share of dividend-constrained firms $\left(d_{t}=0\right.$ and $\left.s_{t}=-\bar{s}\right)$ temporarily rise. They follow an opposite pattern when both dividend and capital gains taxes are cut temporarily. As in Section 3.2, the evolution of the finance regimes illustrates the efficient reallocation effect of the dividend tax cuts and the inefficient reallocation effect of the capital gains tax cuts.

As in our paper, Korinek and Stiglitz (2009) also find that firms cut back investment and pay large special dividends in the period immediately prior to the expiration date of the dividend tax cut (see their Fig. 6). But unlike our paper, they do not predict that investment rises in the period when the dividend tax cut expires. They also do not predict that output, consumption, and TFP may rise temporarily in the transition phase.

To compare our model's predictions with the actual data, we plot the ratio of the total dividend to total capital, the ratio of total equity issuance to total capital, and the aggregate investment rate in Fig. 7. The circled lines present the actual data from the COMPUSTAT over 2002-2008. We assume that the economy in 2002 was in a steady state before the tax cuts. We normalize the actual data and simulated data by their values in 2002. From Fig. 7, we observe that both cases with the temporary and permanent tax cuts capture the fact that aggregate dividends and aggregate equity issuance rose in 2003 in the data. We also observe that, in the data, the aggregate investment rate decreased in 2003. The case with the temporary tax cuts rather than the permanent tax cuts seems to be consistent with this fact. However, we should emphasize that the 

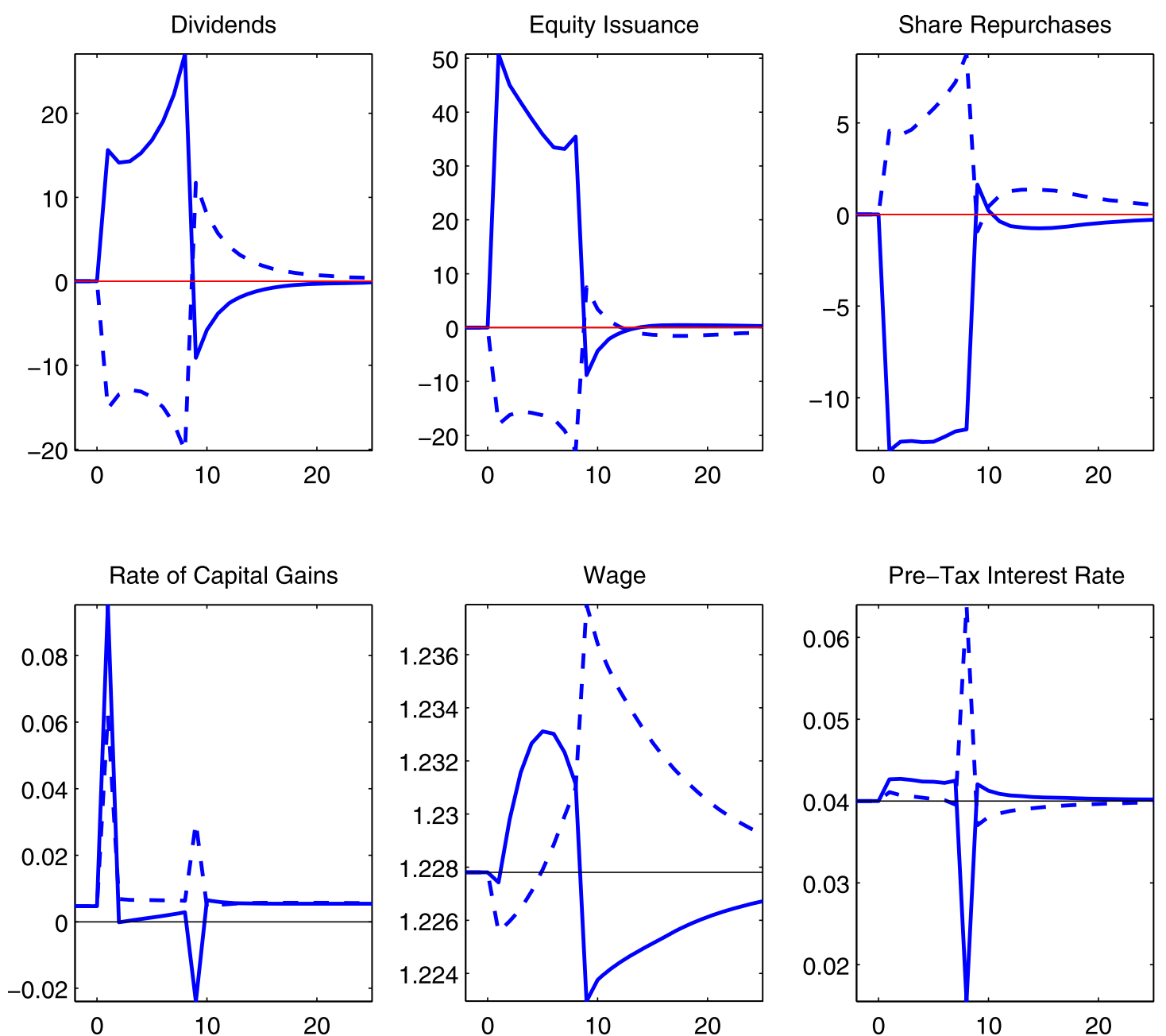

Fig. 5. Impact of unexpected temporary tax cuts in the baseline model. The economy before period 1 is at the initial steady state with parameter values given in Table 1 . The solid lines plot the responses of aggregate dividend payments, equity issuance, share repurchases, the rate of capital gains, wage and the pre-tax interest rate to the unexpected temporary cuts of the dividend tax rate from 0.25 to 0.15 and of the capital gains tax rate from 0.20 to 0.15 . The tax cuts last from periods 1 to 8 . The dashed lines plot the case when only capital gains tax rate is reduced. In each panel, the horizontal axis measures the time period. In the top three panels, the vertical axes measure the percentage deviation from the initial steady state before the tax cuts. In the bottom three panels, the vertical axes measure the actual simulated values after the tax cuts.

investment rate and equity issuance are very volatile in the data partly due to business cycles. Our model abstracts from aggregate uncertainty. This makes it difficult to evaluate the fit of the model during the reform.

\section{Extension: debt financing}

We now extend the baseline model to incorporate debt financing. To keep the model tractable, we consider risk-free debt and ignore the issue of default. Debt has a tax advantage in that interest payments are tax deductible. But debt is limited by a collateral constraint, as in Kiyotaki and Moore (1997) and Hennessy and Whited (2005). Suppose a firm may issue debt $b_{t}$ with interest rate $r_{t}$. We interpret the case with $b_{t}<0$ as saving. The collateral constraint is given by:

$$
\left(1+r_{t}\right) b_{t} \leqslant \eta k_{t}, \quad b_{0} \text { given, }
$$

where $\eta>0$. The firm's flow of funds constraint becomes:

$$
x_{t}+\frac{\psi x_{t}^{2}}{2 k_{t}}+d_{t}+\left(1+r_{t}\right) b_{t}=\left(1-\tau^{c}\right) \pi\left(k_{t}, z_{t} ; w_{t}\right)+\tau^{c}\left(\delta k_{t}+r_{t} b_{t}\right)+s_{t}+b_{t+1} .
$$

Its decision problem is to choose $\left\{b_{t+1}, k_{t+1}, s_{t}, d_{t}, x_{t}\right\}$ so as to maximizes (5) subject to (17), (8), (9), and (16). In this case, there are three state variables $\left(k_{t}, b_{t}, z_{t}\right)$ in the firm's dynamic programming problem. As a result, firms can be differentiated by these three characteristics. In the cross section, there is a distribution $\mu_{t}$ of firms over $\left(k_{t}, b_{t}, z_{t}\right)$. We use this distribution to conduct aggregation. We can then define a competitive equilibrium as in Section 2.4.

We set $\eta=0.3$, which is within the range of estimates of capital resale discounts in Ramey and Shapiro (2001). Our results are robust to changes in this parameter value. In addition, this value implies that the ratio of debt to firm value 
Panel A: Finance Regimes (Capital Gains Tax Cuts Only)

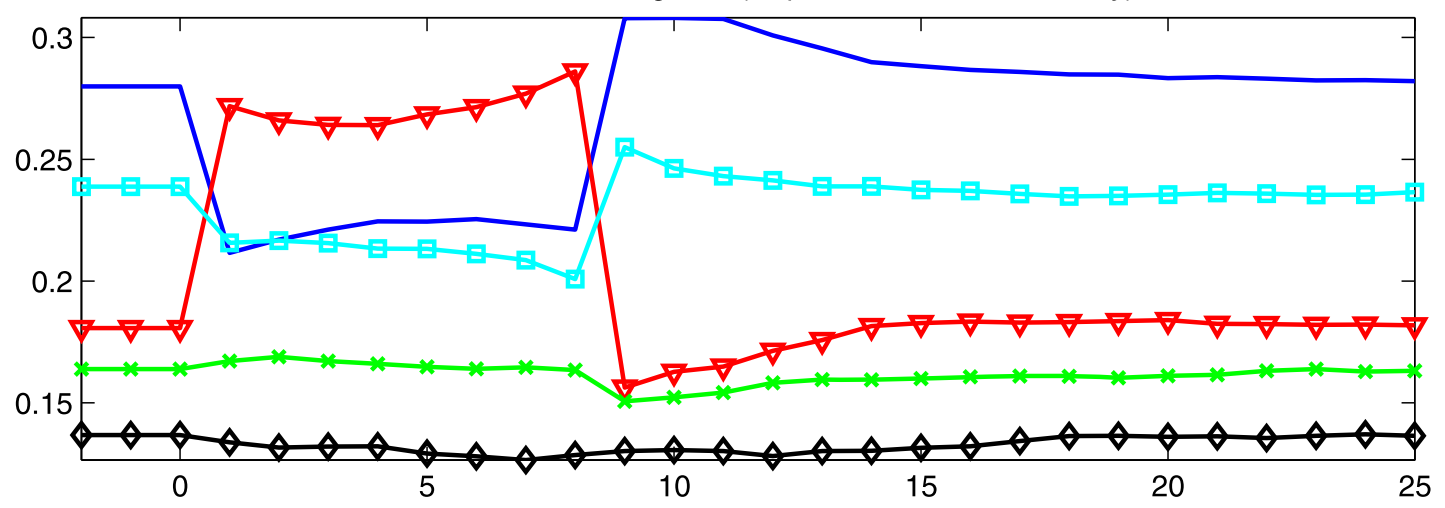

Panel B: Finance Regimes (Dividend and Capital Gains Tax Cuts)

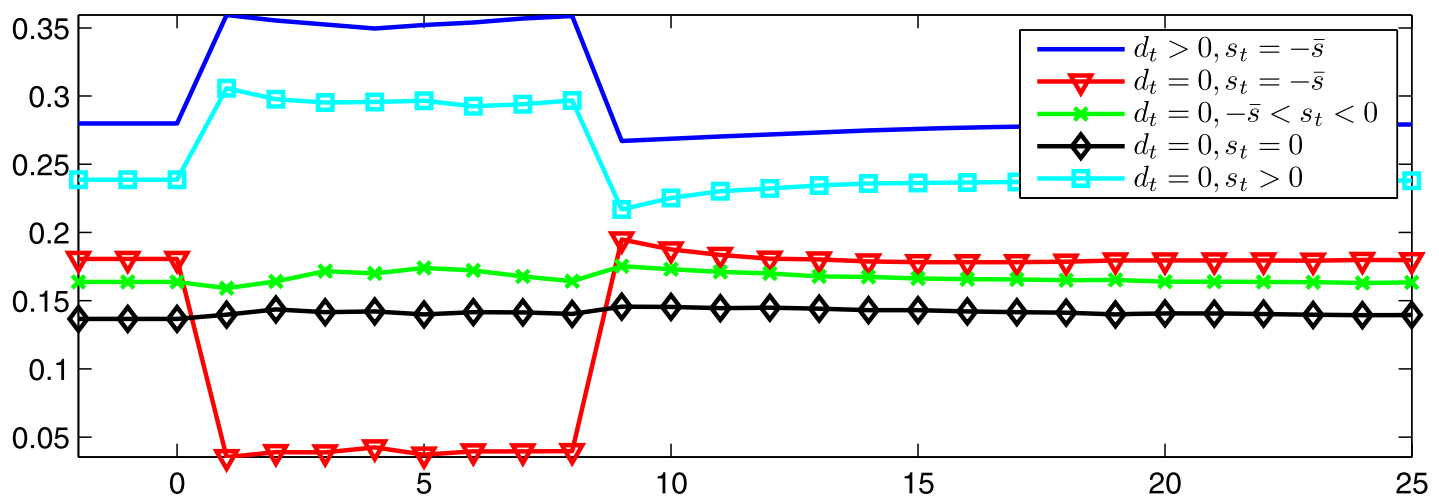

Fig. 6. Impact of unexpected temporary tax cuts in the baseline model. The economy before period 1 is at the initial steady state with parameter values given in Table 1. Panel A plots the evolution of the finance regimes in response to the unexpected temporary cuts of the dividend tax rate from 0.25 to 0.15 and of the capital gains tax rate from 0.20 to 0.15 . The tax cuts last from periods 1 to 8 . Panel B plots the case when only the capital gains tax rate is reduced. The vertical axes measure the shares of firms in each finance regime.
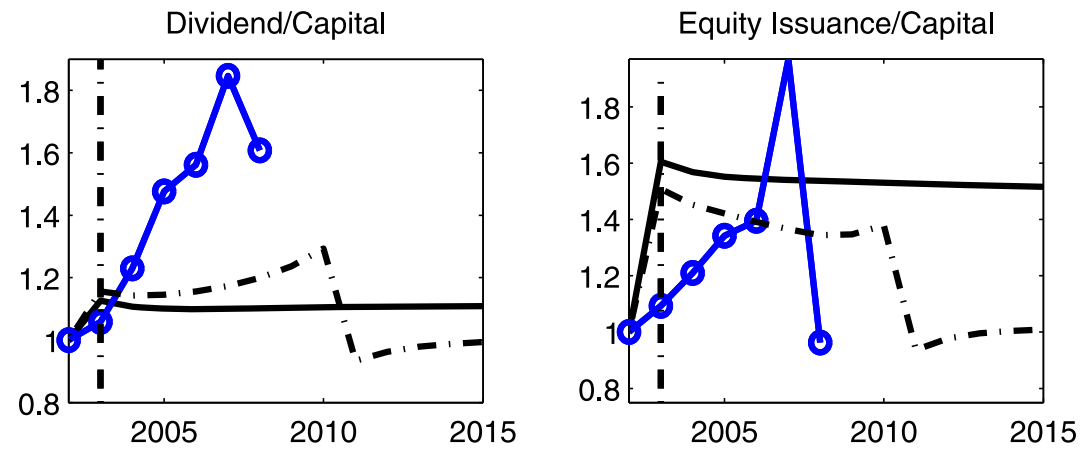

Investment/Capital
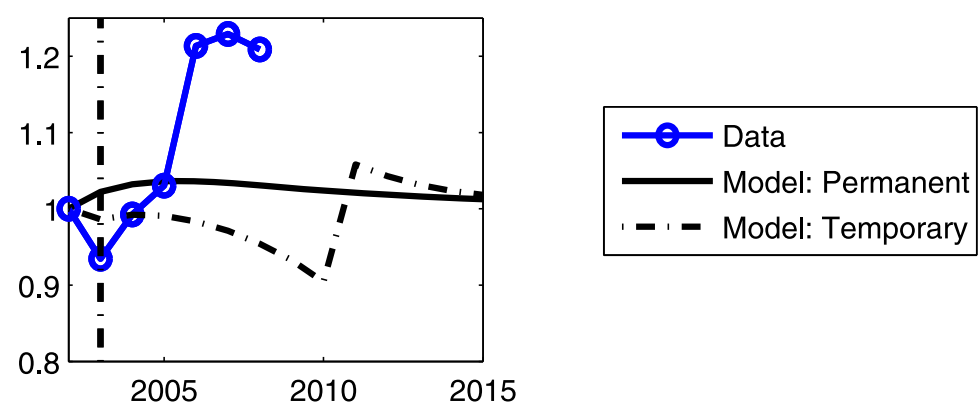

Fig. 7. Comparison of the simulated results and the actual data. The circled lines present the actual data from the COMPUSTAT over 2002-2008. The solid (dashed) lines present the model simulated data assuming that the economy in 2002 was in a steady state and that the dividend and capital gains tax cuts are permanent (temporary). We normalize the actual data and simulated data by their values in 2002. 
is 0.14 , which is within the estimates in the literature. We take all other parameter values as in Table 1 . Based on these parameter values, we solve the model numerically and compare the solution with that in the baseline model. We present our numerical method and detailed results in a separate technical appendix available upon request. Here we just summarize our main findings.

First, the flexibility of using debt and equity financing allows firms to reduce the cost of capital and thus benefits the economy. In particular, the steady-state aggregate real quantities such as investment, capital stock, consumption, employment, and output are all higher in the extended model than in the baseline model. In addition, the impacts of the tax cuts on the economy in the two models are qualitatively similar, though there are some quantitative differences. For instance, the capital stock increases by 3.12 percent following the reform, whereas it is 4.05 percent in the baseline model without debt.

Second, the transitional dynamics of real quantities in the baseline model and in the extended model are similar. The main difference between the two models' predictions is reflected in the financial quantities. In the extended model with debt, firms can borrow or save to transfer cash from the future to the present or from the present to the future. This additional flexibility allows firms to conduct intertemporal tax arbitrage so that they can take greater advantage of low dividend taxes. In the baseline model without debt, in order to take advantage of low dividend taxes, the only way to pay more dividends for firms is to cut back investment, ceteris paribus.

We find that in response to the unexpected and permanent tax cuts, aggregate debt rises over time. This is because the collateral constraints are gradually relaxed as firms build up capital stock over time. Because firms can borrow against their future earnings, they can distribute more dividends initially to take advantage of the dividend tax cut immediately.

When the dividend and capital gains tax cuts are unexpected and temporary, firms raise more debt to distribute more dividends when dividend taxes are low. As in the baseline model without debt, firms also cut back investment to pay more dividends. Overall, the transitional dynamics of real quantities are very similar in the models with and without debt, but dividends and equity issuance are more volatile in the extended model with debt.

\section{Conclusion}

We have developed a dynamic general equilibrium model to study the impact of the 2003 dividend and capital gains tax cuts. In the model, firms are subject to idiosyncratic productivity shocks. They choose investment and financial policies subject to capital adjustment costs, equity issuance costs, and collateral constraints. We find that, when the dividend and capital gains tax cuts are unexpected and permanent, the aggregate real quantities such as output, consumption, labor, investment, and capital all increase in the steady state. During the transition path, aggregate capital rises monotonically over time and investment rises in the short to medium run. By contrast, when these tax cuts are unexpected and temporary, the steady state does not change. Aggregate investment decreases and dividend payments increase during the periods when the tax cuts are implemented. In addition, aggregate output rises temporarily in the short run due to the increase in labor and the positive capital reallocation effect, measured by the temporary increase in TFP. When the tax cuts expire, investment surges and dividend payments fall. We find that these results are robust to the introduction of debt financing. Without debt financing, in order to take advantage of low dividend taxes, the only way for firms to pay more dividends is to cut back investment, ceteris paribus. With debt financing, firms can conduct intertemporal tax arbitrage by borrowing or saving to transfer cash across time. We also show that having the opportunity to choose between equity and debt financing reduces the cost of capital. Consequently, the steady-state aggregate real quantities are higher than those in an otherwise identical model without debt.

\section{Appendix A. Numerical method}

We present the numerical method used to solve the model without debt. In a separate appendix, we present the numerical method and results for the extended model with debt. The algorithm consists of two parts. First, we compute the steady state for given tax rates $\left(\tau^{c}, \tau^{d}, \tau^{g}, \tau^{i}\right)$. Second, we compute the transition path from the initial steady state prior to the tax changes to the new steady state after the tax changes.

\section{A.1. Steady state}

To solve for a steady state, we proceed in three steps. First, for a given wage, we compute a single firm's optimal decision rules. Next, we compute the stationary distribution. Finally, we check whether the labor market equilibrium condition holds; if not, we adjust the wage and go back to the first step. We now provide more details about each step.

Step 1. Starting with a guess of wage $w$, solve the firm's dynamic programming problem by value function iteration on a grid. We use a grid with 600 points for the capital stock and 10 points for productivity shocks. The grid for the capital stock is finer for low values of capital. The lower bound for capital is 0.001 and the upper bound is chosen so that it binds with very small probabilities in a stationary equilibrium. The grid for productivity shocks is taken from Joao Gomes' program, which implements the usual Tauchen and Hussey (1991) approximation for an AR(1) process.

Step 2. After obtaining decision rules from Step 1, we solve for the stationary distribution of firms $\mu^{*}(k, z ; w)$. To do so, we simply iterate on Eq. (13), defined in the main text, starting from a uniform distribution over $(k, z)$. 
Step 3. After obtaining the stationary distribution of firms, we derive the aggregate labor demand $L^{d}(w)=\sum_{k, z} \mu^{*} \times$ $(k, z ; w) l(k, z ; w)$. We then check whether the labor market clears, i.e. whether the equation $-U_{2}\left(C, L^{d}(w)\right) / U_{1}\left(C, L^{d}(w)\right)=$ $\left(1-\tau^{i}\right) w$ holds, where aggregate consumption $C$ is deduced from the resource constraint and the stationary distribution. If the equilibrium condition is not satisfied, we use the bisection method to update the wage rate and go back to Step 1.

\section{A.2. Transitional dynamics}

Assume that the economy starts in the steady state associated with the constant tax rates $\left(\tau_{0}^{g}, \tau_{0}^{d}\right)$. Assume that for $t \geqslant T$, the economy reaches a new steady state with constant tax rates $\left(\tau_{T}^{g}, \tau_{T}^{d}\right)$. We can then solve the transitional dynamics implied by a sequence of tax rates $\left\{\tau_{t}^{d}, \tau_{t}^{g}\right\}_{t=0}^{T}$, as follows:

Step 1. Compute the initial steady state associated with tax rates $\left(\tau_{0}^{g}, \tau_{0}^{d}\right)$, and the new steady state associated with tax rates $\left(\tau_{T}^{g}, \tau_{T}^{d}\right)$. Denote the initial steady-state quantities with a bar, e.g. $\bar{C}, \bar{K}$, etc., and the associated cross-sectional distribution by $\bar{\mu}(k, z)$. Denote the new steady state with a star, e.g. $C^{*}, K^{*}$, and the associated cross-sectional distribution by $\mu^{*}(k, z)$.

Step 2. Guess a path for the interest rate $\left\{r_{t+1}\right\}_{t=1}^{T}$ and a path for the wage rate $\left\{w_{t}\right\}_{t=1}^{T}$.

Step 3. Given $\left\{w_{t}, r_{t}\right\}$, solve the firm's dynamic programing problem by finite backward induction, assuming that $V_{T}(k, z)$ is the new steady-state value function $V^{*}(k, z)$. Deduce the policy function $k_{t+1}=g_{t}(k, z)$.

Step 4. Given the policy functions calculated in Step 3, compute the cross-sectional distribution for any time $t$, using Eq. (13). For $t=0, \mu_{t}=\bar{\mu}$. Then, obtain $\mu_{t}$ for any $t=1,2, \ldots, T$. Deduce the aggregates $Y_{t}, N_{t}, C_{t}$, for $t=1, \ldots, T-1$, using aggregation and the resource constraints.

Step 5. Check if the interest rate and wage are consistent with market clearing. More precisely, define

$$
\begin{aligned}
& \hat{w}_{t}=-U_{2}\left(C_{t}, N_{t}\right) /\left(\left(1-\tau^{i}\right) U_{1}\left(C_{t}, N_{t}\right)\right), \\
& \hat{r}_{t+1}=U_{1}\left(C_{t}, N_{t}\right) /\left(\beta U_{1}\left(C_{t+1}, N_{t+1}\right)\right) /\left(1-\tau^{i}\right)-1,
\end{aligned}
$$

where $C_{T}=C_{T+1}=C^{*}$. If $\max _{t=1, \ldots, T}\left|\hat{w}_{t}-w_{t}\right|+\left|\hat{r}_{t+1}-r_{t+1}\right|$ is less than a precision threshold, stop. Otherwise, update both paths $\left\{r_{t}, w_{t}\right\}$ as follows and return to Step 3:

$$
\begin{aligned}
& w_{t}^{\text {new }}=(1-\rho) w_{t}+\rho \hat{w}_{t}, \\
& r_{t+1}^{\text {new }}=(1-\rho) r_{t+1}+\rho \hat{r}_{t+1} .
\end{aligned}
$$

In practice, we set $\rho=0.9$.

\section{References}

Abel, Andrew B., 1982. Dynamic effects of permanent and temporary tax policies in a q model of investment. Journal of Monetary Economics 9, $353-373$. Allen, Franklin, Michaely, Roni, 2003. Payout Policy, Handbook of the Economics of Finance. North Holland. Auerbach, Alan J., 1979. Wealth maximization and the cost of capital. Quarterly Journal of Economics 93, 433-446.

Auerbach, Alan J., 1989. Tax reform and adjustment costs: the impact on investment and market value. International Economic Review 30, $939-942$.

Auerbach, Alan J., 2002. Taxation and corporate financial policy. In: Auerbach, Alan, Feldstein, Martin (Eds.), Handbook of Public Economics, vol. 3. North Holland, Amsterdam.

Auerbach, Alan J., Hassett, Kevin A., 2003. On the marginal source of investment finance. Journal of Public Economics 87, $205-232$.

Auerbach, Alan J., Hines, James R. Jr., 1987. Anticipated tax changes and the timing of investment. In: Feldstein, Martin, et al. (Eds.), The Effects of Taxation on Capital Accumulation. The University of Chicago Press, Chicago, pp. 163-196.

Auerbach, Alan J., Kotlikoff, Laurence J., 1987. Dynamic Fiscal Policy. Cambridge University Press, Cambridge, UK.

Bradford, David, 1981. The incidence and allocation effects of a tax on corporate distributions. Journal of Public Economics 15, 1-22.

Brennan, Michael J., Thakor, Anjan V., 1990. Shareholder preferences and dividend policy. Journal of Finance 45, 993-1018.

Buera, Francisco, Yongseok, Shin, 2009. Productivity growth and capital flows: the dynamics of reforms. Working paper, UCLA.

Chen, Hsuan-Chi, Ritter, Jay R., 2000. The seven percent solution. Journal of Finance 55, 1105-1131.

Chetty, Raj, Saez, Emmanuel, 2005. Dividend taxes and corporate behavior: evidence from the 2003 dividend tax cut. Quarterly Journal of Economics 120 , $791-833$.

Gomes, Joao, 2001. Financing investment. American Economic Review 91, 1263-1285.

Gordon, Roger, Dietz, Martin, 2006. Dividends and taxes. NBER working paper 12292.

Gourio, François, Miao, Jianjun, 2010. Firm heterogeneity and the long-run effects of dividend tax reform. American Economic Journal: Macroeconomics 2, $131-168$.

Hall, Robert E., 2009. Reconciling cyclical movements in the marginal value of time and the marginal product of labor. Journal of Political Economy 117, 281-323.

Hennessy, Christopher, Whited, Toni, 2005. Debt dynamics. Journal of Finance 60, 1129-1165.

House, Christopher L., Shapiro, Matthew D., 2006. Phased in tax cuts and economic activity. American Economic Review 96, $1835-1849$.

King, Mervyn A., 1977. Public Policy and the Corporation. Chapman and Hall, London.

Kiyotaki, Nobuhiro, Moore, John, 1997. Credit cycles. Journal of Political Economy 105, 211-248.

Korinek, Anton, Stiglitz, Joseph E., 2009. Dividend taxation and intertemporal tax arbitrage. Journal of Public Economics 93, $142-159$.

Ljungqvist, Lars, Sargent, Thomas J., 2004. Recursive Macroeconomic Theory, 2nd edition. MIT Press.

McGrattan, Ellen R., Prescott, Edward C., 2005. Taxes, regulations, and the value of U.S. and U.K. Corporations. The Review of Economic Studies 72, 767-796.

Miller, Merton H., Modigliani, Franco, 1961. Dividend policy, growth, and the valuation of shares. Journal of Business 34, 411-433.

Poterba, James M., Summers, Lawrence H., 1983. Dividend taxes, corporate investment, and Q. Journal of Public Economy 22, $135-167$. 
Poterba, James M., Summers, Lawrence H., 1985. The economic effects of dividend taxation. In: Altman, E., Subrahmanyam, M. (Eds.), Recent Advances in Corporate Finance. Richard D. Irwin, Homewood, IL, pp. 227-284.

Ramey, Valerie A., Shapiro, Matthew D., 2001. Displaced capital: A study of aerospace plant closings. Journal of Political Economy 109, 958-992.

Restuccia, Diego, Rogerson, Richard, 2008. Policy distortions and aggregate productivity with heterogeneous establishments. Review of Economic Dynamics 11, 707-720.

Sinn, Hans-Werner, 1991. The vanishing Harberger triangle. Journal of Public Economics 45, 271-300.

Tauchen, George, Hussey, Robert, 1991. Quadrature based methods for obtaining approximate solutions to nonlinear asset pricing models. Econometrica 59, 371-396. 